\title{
Samowolne oddalenie w myśl art. 338 kodeksu karnego
}

\section{Unauthorized departure from a military unit in the sense of article 338 Penal Code}

\section{Streszczenie:}

W artykule przedstawiono problematykę związaną z odpowiedzialnością karną żołnierzy za czyn określony w art. 338 Kodeksu Karnego, który dotyczy samowolnego oddalenia $\mathrm{w}$ związku $\mathrm{z}$ przestępstwem przeciwko obowiązkowi pełnienia służby wojskowej. Biorąc pod uwagę profesjonalizację Sił Zbrojnych, artykuł obejmuje stan prawny po 2009 roku kiedy to w Polsce zrezygnowano z żołnierzy zasadniczej służby wojskowej a zastąpiono ich żołnierzami pełniącymi zawodową służbę wojskową. Ponadto dokonano analizy czy przedmiotowa problematyka istnieje, skoro posiadamy żołnierzy zawodowych w Siłach Zbrojnych, a nie z poboru. Żołnierz zawodowy może wypowiedzieć stosunek służby wojskowej w każdym czasie i bez podania przyczyny, należy więc zwrócić uwagę, czy problem samowolnego oddalenia nadal funkcjonuje. Przyjrzano się, czy odpowiedzialność z art. 338 k.k. to pozostałość i relikt zasadniczej służby wojskowej. Zwrócono uwagę, czy po zniesieniu służby zasadniczej zapadały wyroki sądowe w stosunku do żołnierzy zawodowych za samowolne oddalenie.

Słowa kluczowe: prawo, prawo wojskowe, żołnierz, samowolne oddalenie, kodeks karny 
Dominik Rosenau, Maciej Iwiński - Samowolne oddalenie...

\begin{abstract}
:
In the article we presented the issues related to the criminal responsibility of soldiers for the act referred to in Art. 338 of the Penal Code, which deals with Unauthorized departure from a military unit in connection with the crime against the obligation of military service. Taking into account the change to the military service of the Armed Forces, the article covers the legal status after 2009 when the Government in Poland resigned from the idea of conscription soldiers were replaced by professional soldiers serving in the military. In addition, we have analyzed whether the subject of the matter still exists since we have professional soldiers in the Armed Forces, and not from conscription. A professional soldier may terminate military service at any time and without any cause, it is important to note whether the problem of unauthorized departure from a military unit is still present. We looked at whether the responsibility of art. 338 of the Penal Code is a remnant and a relic of conscription military service. We pointed out that after, the resignation from the idea of conscription military service, there were several court sentences against professional soldiers for unauthorized departure from a military unit.
\end{abstract}

Keywords: law, military law, soldier, unauthorized departure from a military unit, the Penal Code

\title{
Wstęp
}

Do roku 2009 w Polsce obowiązywał pobór w celu odbycia zasadniczej służby wojskowej. Jednakże uchwalona przez Sejm 9 stycznia 2009 r. i podpisana przez ówczesnego Prezydenta Lecha Kaczyńskiego Ustawa o zmianie ustawy o powszechnym obowiq̨zku obrony $R P^{1}$, która to weszła w życie 11 lutego 2009 roku, formalnie zakończyła żywot zasadniczej służby wojskowej. Zasadnicza służba wojskowa została zamieniona na „kwalifikację wojskową” jako ocena przydatności młodych mężczyzn do służby wojskowej. Obecnie podczas kwali-

\footnotetext{
1 Ustawa z dnia 16 listopada 2016 r. o zmianie ustawy o powszechnym obowiązku obrony Rzeczypospolitej Polskiej oraz niektórych innych ustaw (Dz. U. 2016 poz. 2138).
} 
fikacji orzeczona zostaje kategoria zdolności A, B, lub D do czynnej służby wojskowej i z urzędu poborowy zostaje przeniesiony do rezerwy. W ten sposób uregulowany zostaje stosunek do służby wojskowej przez „poborowego”. Jednakże, w szczególnych przypadkach na wniosek Rady Ministrów Prezydent RP, może wznowić powołania do odbycia zasadniczej służby wojskowej. Obecnie Siły Zbrojne RP opierają się na żołnierzach pełniących zawodową służbę wojskową lub w formie kandydackiej służby wojskowej. Ponadto Siły Zbrojne RP opierają się także na żołnierzach Obrony Terytorialnej lub Narodowych Sił Rezerwowych. Jednakże jest to służba pełniona dobrowolnie przez ochotników.

Zgodnie z Ustawą z dnia 11 września 2003 r. o służbie wojskowej żołnierzy zawodowych ${ }^{2}$ art. 114 pkt. 1 żołnierz zawodowy może w każdym czasie wypowiedzieć stosunek służbowy zawodowej służby wojskowej bez podawania przyczyny, a także zgodnie z art. 111 pkt. 16 żołnierza zawodowego zwalnia się z zawodowej służby wojskowej wskutek nieobecności w służbie jednorazowo przez okres trzech dni roboczych, która nie została usprawiedliwiona. Dlatego należy zastanowić się czy żołnierze pełniący zawodową służbę wojskową ponoszą odpowiedzialność za czyn zabronione zgodnie z art. 338 k.k.:

$\S 1$. Żołnierz, który co najmniej dwukrotnie w okresie nie dłuższym niż 3 miesiące samowolnie opuszcza swoją jednostkę lub wyznaczone miejsce przebywania albo samowolnie poza nimi pozostaje $\mathrm{w}$ wymiarze nieprzekraczającym jednorazowo 48 godzin, podlega karze ograniczenia wolności.

$\S 2$. Żołnierz, który samowolnie opuszcza swoją jednostkę lub wyznaczone miejsce przebywania albo samowolnie poza nimi pozostaje przez okres powyżej 48 godzin, nie dłużej jednak niż przez okres 7 dni, podlega karze ograniczenia wolności, karze aresztu wojskowego do roku albo pozbawienia wolności do roku.

2 Ustawa z dnia 11 września 2003 r. o służbie wojskowej żołnierzy zawodowych (Dz.U.2016.1726 zm. Dz. U. 2017.2138). 
Dominik Rosenau, Maciej Iwiński - Samowolne oddalenie...

$\S 3$ 3. Żołnierz, który samowolnie opuszcza swoją jednostkę lub wyznaczone miejsce przebywania albo samowolnie poza nimi pozostaje przez okres powyżej $7 \mathrm{dni}$, podlega karze aresztu wojskowego albo pozbawienia wolności do lat 3.

$\S 4$. Ściganie przestępstwa określonego w § 1 i 2 następuje na wniosek dowódcy jednostki wojskowej ${ }^{3}$.

\section{Merytoryczne aspekty samowolnego oddalenia}

Wyjaśnienia wymaga definicja pojęcia żołnierz, zgodnie z art. 115. § 17 k.k. Żołnierzem jest osoba pełniąca czynną służbę wojskową, jednakże kodeks karny nie dookreślił, kto jest żołnierzem czynnej służby wojskowej, dlatego też należy sięgnąć do art. 59. pkt. 1 Ustawy o powszechnym obowiązku obrony Rzeczpospolitej Polskiej z dnia 21 listopada 1967 r. ${ }^{4}$. Żołnierzami w czynnej służbie wojskowej, w rozumieniu niniejszej ustawy, są osoby, które odbywają lub pełnią następujące jej rodzaje:

1) zasadniczą służbę wojskową,

2) przeszkolenie wojskowe,

3) terytorialną służbę wojskową,

4) ćwiczenia wojskowe,

5) służbę przygotowawczą,

6) okresową służbę wojskową,

7) służbę wojskową w razie ogłoszenia mobilizacji i w czasie wojny.

Ustawodawca nie wskazuje w tej ustawie żołnierzy zawodowych jako żołnierzy w czynnej służbie wojskowej. Jednakże w Ustawie z dnia 11 września 2003 r. o służbie wojskowej żołnierzy zawodowych $^{5}$ w art. 3. pkt. 1 żołnierze zawodowi są żołnierzami w czynnej służbie wojskowej a także w art. 3. pkt. 1a żołnierze zawodowi pełnią

\footnotetext{
${ }^{3}$ Kodeks Karny - Ustawa z dnia 6 czerwca 1997 r. (Dz.U. 2017 nr 0 poz. 244).

${ }^{4}$ Ustawa o powszechnym obowiązku obrony Rzeczpospolitej Polskiej z dnia 21 listopada 1967 r. (Dz.U.2016 poz.1534).

5 Ustawa z dnia 11 września 2003 r. o służbie wojskowej żołnierzy zawodowych (Dz.U.2016.1726 zm. Dz. U. 2017.2138).
} 
czynną służbę wojskową jako służbę stałą albo służbę kontraktową. Powyższe artykuły wyraźnie wskazują, że żołnierzem zawodowym jest także żołnierz pełniący czynną służbę wojskową. W związku z czym, zgodnie z art. 3. pkt. 2 żołnierze zawodowi pełnią zawodową służbę wojskową dla dobra Rzeczypospolitej Polskiej. Służba ta wymaga zdyscyplinowania, lojalności i poświęcenia. Zgodnie z tą ustawą żołnierz zawodowy jest żołnierzem w czynnej służbie wojskowej a co za tym idzie ponosi odpowiedzialność za czyny z art. 338 k.k.

Należałoby w tym miejscu wyjaśnić, na czym polega samowolne oddalenie się z jednostki wojskowej. Samowolne oddalenie się polega na opuszczeniu przez żołnierza swojej jednostki lub wyznaczonego miejsca przebywania albo pozostawaniu poza nim 6 . Nie mniej ważną kwestią jest wskazanie, czym jest jednostka wojskowa względem wyżej wymienionej definicji. Jednostką wojskową jest rejon rozlokowania oddziału lub pododdziału wojskowego, instytucji wojskowej, szkoły wojskowej itp. Ponadto należy też wyjaśnić że wyznaczonym miejscem przebywania jest rejon poza jednostką wojskową, w którym żołnierz wykonuje określone zadania służbowe7 ${ }^{7}$. Wobec powyższego można stwierdzić, że przedmiotem samowolnego oddalenia się jest obowiązek faktycznego pełnienia służby wojskowej i stanowiący jego konsekwencję - zarówno obowiązek pozostawania w jednostce, do której żołnierz został przydzielony, jak i obowiązek pozostawania poza obrębem macierzystej jednostki w wyznaczonym miejscu do dyspozycji przełożonych. Wspomniany czyn polegać może bądź to na działaniu, tj. opuszczeniu terenu jednostki wojskowej, bądź to na zaniechaniu w postaci pozostania poza jednostką wbrew obowiązkowi powrotu ${ }^{8}$.

Należy zauważyć, że występek ten jest przestępstwem trwałym. Jednym $\mathrm{z}$ elementów konstytutywnych deliktu trwałego jest zatem

\footnotetext{
${ }^{6}$ M. Czyżak, Odrębność polskiego prawa karnego wojskowego wobec prawa karnego powszechnego, Warszawa 2010, s. 214.

7 Tamże, s.214

8 W. Kubala, Przestępstwo dezercji z art. $304 \S 3$ k.k., „Wojskowy Przegląd Prawniczy" 1971, nr 2, s. 156-157.
} 
Dominik Rosenau, Maciej Iwiński - Samowolne oddalenie...

„utrzymywanie” bezprawnego stanu, co nie może mieć miejsca bez woli sprawcy ${ }^{9}$. Rozpoczęcie się biegu przestępstwa trwałego, samowolnego oddalenia, rozpoczyna się w momencie obowiązku powrotu do jednostki wojskowej, a kończy się w momencie dobrowolnego powrotu do miejsca pełnienia służby lub zatrzymania przez odpowiednie organy ${ }^{10}$. Należy pamiętać, że prawnokarna ocena czynu jest uzależniona przede wszystkim od dobrowolnego powrotu do wyznaczonego miejsca pełnienia służby. Ustawodawca za ten typ przestępstwa przewidział karę ograniczenia wolności, karę aresztu wojskowego, albo pozbawienia wolności od roku do lat 3 . W przypadku nieobecności żołnierza przez okres dłuższy niż 7 dni może on podlegać karze pozbawienia wolności do lat 3, jednakże gdy żołnierz wróci do miejsca pełnienia służby w czasie krótszym, niż 7 dni, podlega karze pozbawienia wolności do roku. Na prawnokarną ocenę czynu wpływa także zachowanie żołnierza $\mathrm{w}$ czasie bezprawnego pobytu poza jednostką wojskową oraz argumenty, które kierowały sprawcą. Istotne jest także, że dla bytu przestępstwa z art. 338 k.k. nie ma żadnego znaczenia okoliczność, z jakiego wyznaczonego miejsca przebywania żołnierz dopuszcza się samowolnego oddalenia ${ }^{11}$. Wskazać należy, że zgodnie z art. 338 k.k. § 4 ściganie za przestępstwa określone w § 1 i § 2 następuje na wniosek dowódcy jednostki. W porównaniu z poprzednim stanem prawnym zrezygnowano z karalności przygotowania do samouszkodzenia, czy porozumienia się $w$ celu popełnienia przestępstwa ${ }^{12}$. Jednakże w przypadku żołnierzy zawodowych wchodzi odpowiedzialność dyscyplinarna w związku z popełnieniem rażącego przewinienia dyscyplinarnego. Zgodnie z art. 17 pkt. 1. Ustawy z dnia 9 października 2009 o dyscyplinie wojskowej, żołnierz ponosi

\footnotetext{
${ }^{9}$ K. Banasik, Przestępstwa trwałe i delikty trwałe, „Prokuratura i Prawo” 2013, nr 7-8, s. 96.

10 M. Czyżak, Odrębność polskiego prawa karnego wojskowego wobec prawa karnego powszechnego, Warszawa 2010, s. 215.

11 W. Marcinkowski, Kodeks karny - Część wojskowa. Komentarz, Warszawa 2011, s. 211.

12 R. Góral, Kodeks Karny - Praktyczny komentarz z orzecznictwem. Wydanie V, Warszawa 2007, s. 542.
} 
odpowiedzialność dyscyplinarną za popełnienie przewinienia dyscyplinarnego, posiadającego jednocześnie znamiona innego czynu zabronionego, jeżeli to naruszenie prawa miało związek ze służbą wojskową, niezależnie od odpowiedzialności ponoszonej na podstawie innych przepisów. Zgodnie z art. 17. pkt. 2. ust. 2. Ustawy z dnia 9 października 2009 o dyscyplinie wojskowej, żołnierz ponosi odpowiedzialność dyscyplinarną za czyny o znamionach przestępstwa ściganego na wniosek dowódcy jednostki wojskowej albo wykroczenia ściganego na żądanie dowódcy jednostki wojskowej lub kierownika instytucji wojskowej, jeżeli uprawniony dowódca lub kierownik instytucji cywilnej odstąpił od złożenia wniosku albo żądania. Wobec powyższego, pomimo tego, że dowódca jednostki wojskowej nie wystąpi z wnioskiem o ściganie żołnierza za samowolne oddalenie poniżej $7 \mathrm{dni}$, sprawca poniesie odpowiedzialność dyscyplinarną. W celu wzmocnienia roli dowódcy $\mathrm{w}$ rozpatrywaniu krótkoterminowych samowolnych oddaleni, w art. $338 \S 1$ k.k. ustalono na 48 godzin dolną granicę przestępstwa określonego $\mathrm{w}$ tym przepisie. W tym samym celu zaostrzono też formalne reguły odpowiedzialności karnej za tego rodzaju czyny trwające ponad 7 dni obejmując je - po upływie tego okresu - ściganiem z urzędu, a nie dopiero od $14 \mathrm{dni}$, jak przed nowelizacją ${ }^{13}$. Należy także zauważyć, że czas wolny od zajęć służbowych, który następuje po samowolnym oddaleniu się z jednostki wojskowej lub miejsca pełnienia służby, jest wliczany do trwania okresu przestępstwa. W związku z powyższym żołnierz, który oddali się samowolnie od jednostki np. w piątek a stawi dopiero w poniedziałek to dni wolne od służby tj. sobota i niedziela są wliczane w okres trwania przestępstwa samowolnego oddalenia się.

13 Ministerstwo Obrony Narodowej, Departament Wychowania i Promocji Obronności, Zasady odpowiedzialności karnej żołnierzy w świetle zmian $w$ prawie karnym oraz w prawie wykroczeń, Warszawa 2009, s. 46. 
Dominik Rosenau, Maciej Iwiński - Samowolne oddalenie...

\section{Analiza orzecznictwa}

Istotny jest fakt, czy samowolne oddalenie się pozostało reliktem zasadniczej służby wojskowej, czy problem faktycznie istnieje do dnia dzisiejszego wśród kadry pełniącej zawodową służbę wojskową. Na podstawie przeanalizowanych wyroków można stwierdzić, że mimo iż zawodowy żołnierz może wypowiedzieć stosunek służby w każdym momencie bez podawania przyczyny, problem samowolnego oddalenia się $\mathrm{z}$ jednostki wojskowej lub miejsca pełnienia służby nadal istnieje. Wojskowy Sąd Garnizonowy w O., wyrokiem z dnia 9 lipca 2012 r., uznał st. szer. rez. Daniela A. za winnego tego, że „pełniąc zawodową służbę wojskową w J.W. (...), w okresie nie dłuższym, niż 3 miesiące, samowolnie pozostawał poza jednostką w wymiarze nieprzekraczającym jednorazowo 48 godzin. Wyrok ten został zaskarżony przez prokuratora. Apelacja opierała się na dokonaniu błędnej i niezgodnej z wolą ustawodawcy wykładni art. 338 § 2 k.k., tj. na przyjęciu, iż dni wolnych od służby w okresie samowolnego oddalenia żołnierza zawodowego nie wlicza się do okresu samowolnego oddalenia. Rozpoznając apelację, Wojskowy Sąd Okręgowy postanowieniem z dnia 28 listopada 2012 r., na podstawie art. $441 \S 1$ k.p.k., przekazał Sądowi Najwyższemu do rozstrzygnięcia zagadnienie prawne wymagające zasadniczej wykładni ustawy. Sąd Najwyższy ustalił, że jest to nadal przestępstwo trwałe, które przerwane zostaje dopiero przez dobrowolny powrót żołnierza do dyspozycji organów wojskowych, bądź przymusowe zatrzymanie sprawcy, a czas hipotetycznie wolny od zajęć służbowych w całości zawiera się w nierozdzielnym okresie trwałego przestępstwa samowolnego oddalenia". Następnie ocenił, że „wbrew wskazanemu wyżej dorobkowi orzecznictwa i doktryny na gruncie art. 303 k.k. z 1969 r. oraz art. 338 k.k. prezentuje się (...) teza postanowienia Sądu Najwyższego z 23 kwietnia 2012 r. sygnatura akt: WK 1/12, OSNKW 2012, nr 6, poz. 70 (...), z której wynika, że z uwagi na treść art. 60 ustawy z dnia 11 września 2003 r. o służbie wojskowej żołnierzy zawodowych (Dz.U. z 2010 r. Nr 90, poz. 593 ze zm.) oraz § 4 rozporządzenia Ministra Obrony Narodowej 
z dnia 26 czerwca 2008 r. w sprawie czasu służby żołnierzy zawodowych (Dz.U. z 2008 r. Nr 122, poz. 786), poza sytuacjami szczególnymi przewidzianymi $w$ tych przepisach, żołnierz zawodowy ma obowiązek zgłaszać się do pełnienia służby w swojej jednostce wojskowej lub w innym wyznaczonym miejscu i służbę tę pełnić jedynie w ustalonych przez przełożonych przedziałach czasu, w ramach pięciodniowego tygodnia służby, z wyłączeniem dni ustawowo wolnych od pracy, w dniach od poniedziałku do piątku w godzinach od 7:30 do 15:30. W związku z tym Sąd Najwyższy uznał jako okres samowolnej nieobecności żołnierza zawodowego w służbie wyłącznie te przedziały czasu, w których żołnierz tego obowiązku zaniechał (art. 6 § 1 k.k.). Konsekwencją tego była konstatacja, że ze względu na to, że przestępstwo samowolnego oddalenia jest przestępstwem trwałym, w wypadku popełnienia go przez żołnierza zawodowego dni wolne od służby przerywają okresy utrzymania stanu jego samowolnej nieobecności w swojej jednostce lub w innym wyznaczonym miejscu, podobnie jak w ramach określonego dnia, godziny wolne od służby"14. Zgodnie z orzeczeniem Sądu Najwyższego o sygn. WZP 2/12, Uchwałą Sądu Najwyższego w składzie trzech sędziów z dnia 14 marca 2013 r. znamiona przestępstw określonych $w$ art. 338 § 1, 2 albo 3 k.k. mogą zostać wypełnione przez żołnierza zawodowego tylko wtedy, gdy samowolnie opuszcza on swoją jednostkę lub wyznaczone miejsce przebywania albo samowolnie poza nimi pozostaje w czasie służby regulowanym w art. 60 ust. 1-4 ustawy z dnia 11 września 2003 r. o służbie wojskowej żołnierzy zawodowych (Dz.U. z 2010 r., Nr 90, poz. 593 ze zm.), a zatem w czasie, w którym był zobowiązany do wykonywania obowiązków służbowych lub pozostawania w gotowości do ich wykonywania, co oznacza, że do czasu samowolnego oddalenia nie wlicza się dni i godzin wolnych od służby ${ }^{15}$. W postanowieniu Sądu Najwyższego WK 1/12 w składzie trzech sędziów Sąd Najwyższy w sprawie szer. rez. Grzegorza M., uniewinnionego od

\footnotetext{
14 Wyrok Sądu Najwyższego z dnia 14 marca 2013 r. WZP 2/12.

15 Ibidem.
} 
Dominik Rosenau, Maciej Iwiński - Samowolne oddalenie...

zarzutu popełnienia przestępstwa określonego w art. $338 \S 2$ k.k. po rozpoznaniu w Izbie Wojskowej na rozprawie w dniu 23 kwietnia 2012 r. kasacji wniesionej przez prokuratora na niekorzyść od wyroku Wojskowego Sądu Okręgowego z dnia 13 grudnia 2011 r., utrzymującego w mocy wyrok Wojskowego Sądu Garnizonowego z dnia 23 września 2011 r., oddalił kasację. Podzielając wskazane poglądy judykatury i doktryny skarżący wskazał, że skoro na skutek nowelizacji przepisu art. 338 k.k. żołnierze zawodowi zostali poddani tym samym rygorom odpowiedzialności, co dawniej żołnierze służby zasadniczej, to dotychczasowe poglądy wypowiedziane co do przestępstwa trwałego odnosić się powinny do przestępstw tego rodzaju popełnionych przez żołnierzy zawodowych. Szczegółowe określenie czasu służby nastąpiło na mocy rozporządzenia Ministra Obrony Narodowej z dnia 26 czerwca 2008 r. w sprawie czasu służby żołnierzy zawodowych (Dz. U. Nr 122, poz. 786). W § 4 rozporządzenia określono, że przełożeni ustalają zadania służbowe żołnierzy w sposób pozwalający na wykonanie zadań w pięciodniowym tygodniu służby, z wyłączeniem dni ustawowo wolnych od pracy, w dniach od poniedziałku do piątku, w godzinach od 7.30 do 15.30. Zatem, zgłaszając się w miejscu pełnienia służby w wyznaczonych dniach i godzinach żołnierz zawodowy czyni zadość ciążącemu na nim obowiązkowi w zakresie przestrzegania czasu służby. Skoro żołnierz zawodowy nie ma obowiązku zgłaszania się do miejsca służby w innych dniach niż wyznaczone oraz w innych godzinach w wyznaczonych dniach i tego nie czyni, to nie można zasadnie twierdzić, że nie dopełnia on w tym czasie ciążącego na nim obowiązku i dopuszcza się zaniechania przedstawiającego się jako przestępstwo samowolnego oddalenia. Wskazać należy, że moment końcowy przestępstw określonych w art. $338 \S 1$ i 2 k.k. jako przestępstw trwałych to chwila uczynienia zadość obowiązkowi (zgłoszenie się do służby lub powrócenie do jednostki) lub chwila zatrzymania. Momentem końcowym jest również chwila, w której na sprawcy przestał ciążyć określony obowiązek (arg. z art. $104 \S 1$ k.k.). Charakteryzując stronę podmiotową tego przestępstwa wskazać należało, że sprawcę cechuje nie za- 
miar uchylenia się od pełnienia służby wojskowej w ogóle, lecz jedynie zamiar uchylenia się na pewien czas od określonego obowiązku wynikającego z pełnienia tej służby. Zatem dni wolne od służby przerywają okresy utrzymywania stanu bezprawnego. Taka wykładnia czasu trwania przestępstwa samowolnego oddalenia pozostaje w zgodzie z zasadą wolności człowieka określoną w art. 31 Konstytucji RP, ma więc charakter prokonstytucyjny ${ }^{16}$. Powyższy pogląd także podzielił Sąd Najwyższy w składzie trzech sędziów w postanowieniu z dnia 12 lutego 2013 o sygn. WK 3/12. sprawie szer. rez. M. G. uniewinnionego od zarzutu popełnienia przestępstwa określonego $\mathrm{w}$ art. 338 § 2 k.k., po rozpoznaniu w Izbie Wojskowej na rozprawie w dniu 12 lutego 2013 r., kasacji wniesionej przez prokuratora Wojskowej Prokuratury Okręgowej na niekorzyść oskarżonego od wyroku Wojskowego Sądu Okręgowego z dnia 4 stycznia 2012 r., utrzymującego w mocy wyrok Wojskowego Sądu Garnizonowego z dnia 25 października 2011 r., Sąd Najwyższy w przedmiotowej sprawie oddalił kasację wniesioną przez prokuratora Wojskowej Prokuratury Okręgowej ${ }^{17}$. W przedmiotowej sprawie Sąd Najwyższy podtrzymywał stanowisko jak we wcześniej przytoczonych wyrokach.

\section{Zakończenie}

Po przeanalizowaniu orzecznictwa dotyczącego samowolnego oddalania się żołnierzy zawodowych zgodnie z art. 338 k.k. należy stwierdzić, że problem samowolnego oddalenia wśród kadry nadal istnieje aczkolwiek głównie wśród korpusu szeregowych zawodowych, którzy to zastąpili zasadniczą służbę wojskową. Należy zwrócić także uwagę, że istnieje rozbieżny pogląd na fakt przerywania czynu samowolnego oddalenia się związanego $\mathrm{z}$ dniami ustawowo wolnymi od służby. Dni wolne od służby przerywają okresy utrzymywania stanu bezprawnego. Wskazać należy, że żołnierze zawodowi ponoszą

\footnotetext{
16 Postanowienie Sądu Najwyższego z dnia 23 kwietnia 2012 r. WK 1/12.

17 Postanowienie Sądu Najwyższego z dnia 12 lutego 2013 r. WK 3/12.
} 
Dominik Rosenau, Maciej Iwiński - Samowolne oddalenie...

odpowiedzialność także dyscyplinarną wewnątrz jednostki wojskowej, w której służą z art. 60a pkt. 1 Ustawy z dnia 11 września 2003 roku o służbie wojskowej żołnierzy zawodowych. Ponadto żołnierz jest obligatoryjnie zwalniany ze służby, jeżeli przez trzy kolejne dni służby nie stawi się w swojej jednostce, a jego nieobecność będzie nieusprawiedliwiona, wobec czego samowolne oddalenie się może przynieść dla żołnierza zawodowego, który dobrowolnie pełni służbę, bardzo negatywne skutki.

\section{Bibliografia:}

Banasik K., Przestępstwa trwałe i delikty trwałe, „Prokuratura i Prawo” 2013, nr 7-8.

Czyżak M., Odrębność polskiego prawa karnego wojskowego wobec prawa karnego powszechnego, Warszawa 2010.

Góral R., Kodeks Karny - Praktyczny komentarz z orzecznictwem. Wydanie V, Warszawa 2007.

Kodeks Karny - Ustawa z dnia 6 czerwca 1997 r. (Dz.U. 2017 nr 0 poz. 244).

Konstytucja Rzeczpospolitej Polskiej z dnia 2 kwietnia 1997 r. (zm. Dz.U. 2009 nr 114 poz. 946).

Kubala W., Przestępstwo dezercji z art. 304 \& 3 k.k., „Wojskowy Przegląd Prawniczy" 1971, nr 2.

Marcinkowski W., Kodeks karny - Część wojskowa. Komentarz, Warszawa 2011.

Postanowienie Sądu Najwyższego z dnia 12 lutego 2013 r. WK 3/12.

Postanowienie Sądu Najwyższego z dnia 23 kwietnia 2012 r. WK 1/12.

Regulamin Ogólny Sił Zbrojnych Rzeczpospolitej Polskiej, Ministerstwo Obrony Narodowej - Sztab Generalny Wojska Polskiego, Warszawa 2014 sygn. Szt. Gen. 1664/2014.

Ustawa z dnia 11 września 2003 r. o służbie wojskowej żołnierzy zawodowych (Dz. U. 2016.1726 zm. Dz. U. 2017.2138).

Ustawa o powszechnym obowiązku obrony Rzeczpospolitej Polskiej z dnia 21 listopada 1967 r. (Dz.U. 2016 poz.1534).

Wyrok Sądu Najwyższego z dnia 14 marca 2013 r. WZP 2/12. 
Zasady odpowiedzialności karnej żołnierzy $w$ świetle zmian $w$ prawie karnym oraz $w$ prawie wykroczeń, Ministerstwo Obrony Narodowej - Departament Wychowania i Promocji Obronności, Warszawa 2009.

Zbiór wojskowych przepisów dyscyplinarnych oraz dotyczących wojskowych organów porządkowych, Ministerstwo Obrony Narodowej - Departament Wychowania i Promocji Obronności, Warszawa 2011 sygn. Dep. Wych. $15 / 2011$. 